Tohoku J. exp. Med., 1973, 110, 59-68

\title{
Effect of Diphenylhydatoin Therapy on Folate Metabolism of Mentally Retarded Epileptics
}

\author{
Tsuneo Arakawa, Toshio Yoshida, Yoshiyuki Honda, \\ Kuntaki Narisawa, Haruko Hrrono, Tadashi Hayashi, \\ Shuji Tsuchida, Shinobu Chida* and Aya Kuwabara* \\ Department of Pediatrics, Tohoku University School of Medicine \\ and Nishitaga National Hospital, ${ }^{*}$ Sendai
}

Arakawa, Ts., Yoshida, T., Honda, Y., Narisawa, K., Htrono, H., Hayashi, T., Tsucmoa, S., ChIDA, S, and Kuwabara, A. Effect of Diphenylhydantoin Therapy on Folate Metabolism of Mentally Retarded Epileptics. Tohoku J. exp. Med, 1973, 110 (1), 59-68_... Either a rise or fall in sorum folate levels was observed in mentally retarded epilepties with diphenylhydantoin therapy. Urinary excretion of FICHLU after an oral histidine load was decreased significantly in patients with the anticonvulsant therapy. Eleven cases out of 37 cases with diphenylhydantoin administration showed a positive ferric chloride reaction of urine collected after an oral histidine load. The positive ferric chloride reaction was proved to be due to the presence of imidazole pyruvic acid, suggesting a defective activity of the hepatic histidase of epileptics with the drug therapy. It was suggested that the decreased urinary FIGLU during the drug therapy might be partly resulted from a defective activity of the hepatic histidase which was caused by diphenylhydantoin therapy. Serum vitamin $B_{12}$ levels, MCV and an incidence of hvpersegmentation of neutrophil nuelei showed no difference between patients with diphenylhydantoin therapy and those without it.

folic acid; histidase; FTGLU; diphenylhydantoin

The present study was undertaken to investigate an effect, if any, of diphenylhydantoin administration upon serum folate and vitamin $B_{12}$ levels, MCV of erythrocytes, lobe average of neutrophil nuclei, formiminoglutamic acid (FIGLU) and $\mathrm{FeCl}_{3}$ tests of urine specimens after an oral histidine load in mentally retarded patients.

\section{Materials and Methods}

Seventy-four mentally retarded patients with or without convulsions, aged between 6 and 28 years, staying at the Nishitaga National Hospital, were subjected to this study.

They were divided into two groups (Groups I and II). Group I consisted of 37 cases (Nos. 1-37) who received no anticonvulsants. Group II consisted of 37 cases (Nos. 3874) who were treated with diphenylhydantoin plus phenobarbital for their seizures for a period ranging from 6 months to 17 years (cf. Tables 1 and 2 ).

Blood samples were taken in the morning after a night's fast, and assayed for vitamin $\mathrm{B}_{12}$ and folate ( $L$. casei) levels in serum by Lau ef al.'s method (1965) and a modification of Herbert's method (1961), respectively.

Received for publication, September 14, 1972. 
Formiminoglutamic acid (FIGLU) was estimated by Tabor and Wyngarden's method (1959) on 8-hour-urine specimens after an oral administration of L-histidine monohydrochloride, $0.33 \mathrm{~g}$ per $\mathrm{kg}$ body weight.

By using the same urine spacimens the ferric chloride reaction was tested.

Serum histidine levels were determined using an automatic amino acid analyzer before and at the end of 4 hours after the histidine load.

The lobe average of neutrophil nuclei of the peripheral blood was determined according to Herbert's description (1965).

TABLE 1. Serum vitamin $B_{12}$ and folate levels, $M C V$, lobe

\begin{tabular}{|c|c|c|c|c|c|}
\hline $\begin{array}{c}\text { No. } \\
\text { of } \\
\text { case }\end{array}$ & Name & $\begin{array}{l}\text { Age } \\
(y .)\end{array}$ & Sex & $\begin{array}{l}\text { Clinical diagnosis } \\
\text { and remarks }\end{array}$ & $\begin{array}{c}\text { Serum } B_{12} \\
(\mathrm{~m} \gamma / \mathrm{ml})\end{array}$ \\
\hline 1 & T.K. & 6 & $\$$ & C.P.* & 0.52 \\
\hline 2 & K.K. & 6 & 今 & C.P. Premature & 0.98 \\
\hline 3 & K.T. & 8 & $\delta$ & C.P. Asphyxia & 0.58 \\
\hline 4 & o.s. & 8 & $\delta$ & Down's syndrome & 0.45 \\
\hline 5 & S.R. & 6 & $B$ & C.P. & 0.98 \\
\hline 6 & K.K. & 10 & $\$$ & C.P. Cat's cry syndrome & 0.48 \\
\hline 7 & S.S. & 10 & 우 & C.P. Premature & 0.37 \\
\hline 8 & N.Z. & 10 & $\delta$ & C.P. Sturge-Weber's d. & 0.46 \\
\hline 9 & N.H. & 10 & 우 & C.P. Hydrocephalus & 0.23 \\
\hline 10 & S.B. & 11 & 9 & C.P. & 0.19 \\
\hline 11 & O.M. & 12 & 우 & Hyperalaninemia & 0.52 \\
\hline 12 & M.C. & 13 & 우 & C.P. & 0.31 \\
\hline 13 & S.M. & 13 & 우 & C.P. Encephalopathy at $6 \mathrm{~m}$. & 0.35 \\
\hline 14 & A.U. & 14 & 우 & C.P. Asphyxia & 0.23 \\
\hline 15 & I.M. & 14 & 9 & C.P. Encephalopathy at I y. & 0.42 \\
\hline 16 & O.T. & 15 & 우 & Down's syndrome & 0.27 \\
\hline 17 & S.C. & 14 & 우 & Down's syndrome & 0.50 \\
\hline 18 & O.T. & 14 & 우 & C.P. & 0.35 \\
\hline 19 & S.A. & 16 & 우 & C.P. & 0.47 \\
\hline 20 & I.K. & 16 & 9 & C.P, Measles encephalitis at $3 y$, & 0.40 \\
\hline 21 & O.S. & 16 & 字 & C.P. & 0.35 \\
\hline 22 & C.I. & 17 & $\delta$ & C.P. Asphyxia & 0.28 \\
\hline 23 & I.M. & 18 & 우 & C.P. Asphyxia & 0.20 \\
\hline 24 & S.K. & 18 & 古 & C.P. Anophthalmos & 0.38 \\
\hline 25 & A.S. & 18 & $\delta$ & Down's syndrome & 0.58 \\
\hline 26 & W.M. & 18 & 우 & $\begin{array}{l}\mathrm{B}_{6} \text { dependent xanthurenic } \\
\text { aciduria }\end{array}$ & 0.54 \\
\hline 27 & U.K. & 19 & 今 & C.P. Kernicterus & 0.40 \\
\hline 28 & N.K. & 20 & 우 & C.P. Asphyxia & 0.34 \\
\hline 29 & A.M. & 20 & 우 & $\begin{array}{l}\text { C.P. Measles encephalopathy } \\
\text { at } 3 y \text {. }\end{array}$ & 0.31 \\
\hline 30 & K.K. & 20 & 우 & C.P. & 0.14 \\
\hline 31 & H.K. & 21 & 우 & C.P. & 0.50 \\
\hline 32 & K.A. & 21 & 우 & C.P. & 0.34 \\
\hline 33 & I.K. & 17 & 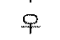 & Congenital syphilis & 0.21 \\
\hline 34 & D.S. & 22 & 우 & Histidinemia & 0.28 \\
\hline 35 & K.K. & 23 & 우 & C.P. & 0.42 \\
\hline 36 & K.K. & 23 & 우 & C.P. Encephalopathy at $3 \mathrm{y}$. & 0.87 \\
\hline 37 & I.K. & 18 & 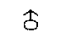 & C.P. Asphyxia & 0.34 \\
\hline Average & & & & & $0.43 \pm 0.05$ \\
\hline
\end{tabular}

* C.P. = cerebral palsy 


\section{Results and Discussion}

(1) Ferric chloride reaction of urine specimens after an oral histidine load in patients with or without diphenylhydantoin therapy: All the 74 patients were tested for the ferric chloride reaction of urine specimens collected for 8 hours after an oral dose of L-histidine monohydrochloride, $0.33 \mathrm{~g}$ per $\mathrm{kg}$. Only 11 cases gave the positive reaction, of which 10 cases (Nos. 42, 46, 49, 50, 57, 59, 61, 62, 64 and 67) were belonged to Group II and the remaining one (No. 34, histidinemia) to

average of neutrophils, urinary $F I G L U$ and $\mathrm{FeCl}_{3}$ test of mentally anticonvulsant therapy (Group 1)

\begin{tabular}{|c|c|c|c|c|}
\hline $\begin{array}{l}\text { Serum folate } \\
\qquad(\mathrm{m} \gamma / \mathrm{ml})\end{array}$ & $\begin{array}{l}\text { Lobe average } \\
\text { of neutrophils }\end{array}$ & $\operatorname{MCV}\left(\mu^{3}\right)$ & $\begin{array}{l}\text { FIGLU after } \\
\text { oral dose of } \\
\text { histidine ( } \mu \text { moles } \\
\text { per } 8 \text { hr. urine) }\end{array}$ & $\mathrm{FeCl}_{3}$ test \\
\hline 11.4 & 2.49 & 106 & 18.2 & - \\
\hline 10.0 & 3. 22 & 94 & 17.8 & - \\
\hline 50.8 & 2.01 & 104 & 43.2 & - \\
\hline 10.5 & 1.66 & 99 & 18.9 & - \\
\hline 9.1 & 2.57 & 93 & 38.1 & - \\
\hline 35.0 & & 100 & 7.2 & - \\
\hline 66.0 & & 77 & 28.0 & - \\
\hline 9.0 & 2.17 & 87 & 33.3 & - \\
\hline 13.3 & 2.40 & 93 & 48.0 & - \\
\hline 17.2 & 2.02 & 93 & 45.6 & - \\
\hline 7.8 & 2.23 & 95 & 35.8 & - \\
\hline 12.8 & 1.98 & 81 & 13.6 & - \\
\hline 9.7 & 1.88 & 120 & 19.8 & - \\
\hline 10.6 & 2. 22 & 98 & 26.8 & - \\
\hline 5.6 & 2.38 & 86 & 34.2 & - \\
\hline 18.2 & 1.68 & 103 & 6.6 & - \\
\hline 10.0 & 2.01 & 107 & 33.4 & - \\
\hline 8.7 & 1.66 & 84 & 37.1 & - \\
\hline 6.1 & 2.03 & 99 & & - \\
\hline 9.3 & 2.27 & 96 & 15.6 & - \\
\hline 15.6 & 2.02 & 77 & 30.9 & - \\
\hline 6.2 & 2.16 & 95 & 32.2 & - \\
\hline 10.1 & 2.26 & 78 & 9.1 & - \\
\hline 9.5 & 2.04 & 93 & & $\ldots$ \\
\hline 12.1 & 1.99 & 118 & 4.9 & - \\
\hline 13.0 & 1.83 & 102 & 33.3 & - \\
\hline 7.7 & 2.57 & 87 & 10.5 & - \\
\hline 5.8 & 1.93 & 87 & 37.7 & - \\
\hline $\begin{array}{r}0.0 \\
10.2\end{array}$ & 1.52 & 92 & 8.8 & - \\
\hline & & & & - \\
\hline 6.6 & 2.43 & 91 & 62.7 & - \\
\hline 6.0 & 2.11 & 75 & 14.0 & - \\
\hline 5.1 & 2. 32 & 106 & 31.1 & - \\
\hline 5.6 & 1.88 & 87 & 61.6 & - \\
\hline 4.7 & 2.25 & 100 & 32.9 & $\theta$ \\
\hline 4.3 & 2.01 & 99 & 40.3 & - \\
\hline 2.6 & 2.48 & 100 & 99.0 & - \\
\hline 9.8 & 2. 49 & 101 & 11.7 & - \\
\hline $12.9 \pm 4.3$ & $2.14 \pm 0.18$ & $94.6 \pm 3.7$ & $27.2 \pm 7.5$ & \\
\hline
\end{tabular}


TABLE 2. Serum vilamin $B_{12}$ and folate levels, retarded patients with

\begin{tabular}{|c|c|c|c|c|c|}
\hline $\begin{array}{c}\text { No. } \\
\text { of } \\
\text { case }\end{array}$ & Name & $\begin{array}{l}\text { Age } \\
\text { (y.) }\end{array}$ & Sex & $\begin{array}{l}\text { Clinical diagnosis } \\
\text { and remarks }\end{array}$ & $\begin{array}{c}\text { Serum } B_{12} \\
(\mathrm{~m} \gamma / \mathrm{ml})\end{array}$ \\
\hline 38 & F.C. & 13 & & C.P.* Asphyxia & 0.65 \\
\hline 39 & S.H. & 7 & & C.P. & 0.50 \\
\hline 40 & Y.M. & 7 & & C.P. Kernicterus & 0.20 \\
\hline 41 & C.Y. & 7 & & C.P. & 0.46 \\
\hline 42 & O.K. & 8 & & C.P. Asphyxia & 0.41 \\
\hline 43 & K.M. & 8 & & C.P. Premature & 0.63 \\
\hline 44 & $\begin{array}{l}\text { A.N. } \\
\text { Y.T. }\end{array}$ & 8 & & $\mathrm{~B}_{\varepsilon}$ depondent homocystinuria & 0.43 \\
\hline 45 & Y.T. & 9 & & C.P. Premature & 0.52 \\
\hline 46 & O. E. & 9 & & G.P. Premature & 0.67 \\
\hline 47 & Y.H. & 9 & & C.P. Asphyxia & 0.33 \\
\hline 48 & S.U. & 10 & & Phenylketonuria & 0.49 \\
\hline 49 & O.S. & 10 & & C.P. Kernicterus & 0.34 \\
\hline 50 & O.J. & 10 & & C.P. Asphyxia & 0.33 \\
\hline 51 & Y.K. & 10 & & C.P. & 0.22 \\
\hline 52 & U.K. & 11 & & C.P. Asphyxia & 0.53 \\
\hline 53 & S.N. & 11 & & Tuberous sclerosis & 0.24 \\
\hline 54 & A.F. & 12 & & C.P. & 0.20 \\
\hline 55 & C.T. & 12 & & C.P. Encephalopathy at $4 \mathrm{y}$. & 0.44 \\
\hline 56 & S.Y. & 12 & & $\mathrm{C}, \mathrm{P}$ & 0.32 \\
\hline 57 & T.B. & 13 & & C.P. & 0.52 \\
\hline 58 & T.K. & 14 & & C.P. Encephalopathy at $3 \mathrm{y}$. & 0.32 \\
\hline 59 & M. K. & 14. & & C.P. & 0.64 \\
\hline 60 & M.E. & 15 & & C.P. & 0.21 \\
\hline 61 & A.Y. & 16 & & C.P. Premature & 0.53 \\
\hline 62 & O.C. & 16 & & $\begin{array}{l}\text { Tuberculous meningitis, urocanic } \\
\text { aciduria }\end{array}$ & 0.48 \\
\hline 63 & o.s. & 16 & & C.P. & 0.34 \\
\hline 64 & $0 . \mathrm{s}$ & 17 & & Mental retardation (familial?) & $\begin{array}{l}. .44 \\
0.42\end{array}$ \\
\hline 65 & S.J. & 17 & & C.P. & 0.22 \\
\hline 66 & S.H. & 18 & & $\mathrm{C} . \mathrm{P}$ & 0.44 \\
\hline 67 & T.M. & 18 & & $\begin{array}{l}\text { C.P. Tuberculous meningitis, } \\
\text { urocanic aciduria }\end{array}$ & 0.20 \\
\hline 68 & F.K. & 18 & & C.P. Encephalopathy at $2 \mathrm{y}$. & 0.49 \\
\hline 69 & K.T. & 18 & & C.P. Encephalopathy at $2 y$. & 1.07 \\
\hline 70 & I.M. & 19 & & C.P. Encephalopathy at 4 y. & 0.60 \\
\hline 71 & S.T. & 20 & & C.P. Measles encephalitis at $11 \mathrm{~m}$. & 0.11 \\
\hline 72 & S.C. & 20 & & C.P. Encephalopathy at 1 y. $2 \mathrm{~m}$. & 0.25 \\
\hline 73 & K.S. & 23 & & Congenital syphilis & 0.72 \\
\hline $\begin{array}{c}74 \\
\text { Averaoe }\end{array}$ & S.E. & 23 & & C.P. Encephalopathy at $3 \mathrm{y}$. & 0.57 \\
\hline
\end{tabular}

C.P. = cerebral palsy

Group I (cf. Tables 1 and 2).

In each of urine specimens with the positive ferric chloride reaction, a considerable amount of imidazole pyruvic acid was detected by a thin-layer chromatography of Humbel's procedure (1970), but no increase in phenylpyruvic acid being found.

In order to evaluate an activity of the hepatic histidase, serum histidine levels were determined before and at the end of 4 hours after an oral dose of Lhistidine monohydrochloride, $0.33 \mathrm{~g}$ per $\mathrm{kg}$ body weight, on 17 patients with 
$M C V$, lobe average of neutrophils, urinxry $\mathrm{FIGLU}$ and $\mathrm{FeCl}_{3}$ test of mentally anticonvulsant therapy (Group II)

\begin{tabular}{|c|c|c|c|c|c|}
\hline $\begin{array}{l}\text { Serum folate } \\
\qquad(\mathrm{m} \gamma / \mathrm{ml})\end{array}$ & $\begin{array}{l}\text { Lobe average } \\
\text { of neutrophils }\end{array}$ & $\operatorname{MCV}\left(\mu^{3}\right)$ & $\begin{array}{l}\text { FIGLU after } \\
\text { oral dose of } \\
\text { histidine }(\mu \text { moles } \\
\text { per } 8 \mathrm{hr} \text {. urine })\end{array}$ & $\mathrm{FeCl}_{3}$ test & $\begin{array}{c}\text { Duration of } \\
\text { administration } \\
\text { of } \\
\text { anticonvulsants }\end{array}$ \\
\hline 8.6 & 2.45 & 104 & 8.6 & - & 2 y. $7 \mathrm{~m}$. \\
\hline 52.0 & 1.65 & 92 & 2.4 & - & 3 y. $7 \mathrm{~m}$. \\
\hline 3.2 & 1.73 & 100 & 24.8 & - & $5 \mathrm{y}$ \\
\hline 12.1 & & 103 & 13.5 & - & $1 \mathrm{y}$. \\
\hline 33.0 & 1.95 & 93 & 6.2 & $\theta$ & $2 \mathrm{y} .4 \mathrm{~m}$ \\
\hline 2.6 & 1.59 & 87 & 0 & - & 2 y. $4 \mathrm{~m}$. \\
\hline 3.3 & 1.95 & 97 & 8.1 & - & $8 \mathrm{y}$. \\
\hline 7.6 & 2.65 & 110 & 4.8 & - & $4 \mathrm{y}$ \\
\hline 39.3 & 2.00 & 88 & 0 & $\theta$ & $9 \mathrm{y}$ \\
\hline 4.9 & 2.24 & 89 & 9.6 & - & $2 \mathrm{y}$. \\
\hline 5. 2 & 2.45 & 129 & 19.1 & - & $4 y$ \\
\hline 14.6 & 2. 29 & 67 & 7.9 & $i H$ & $2 \mathrm{y}$. \\
\hline 57.9 & 2.03 & 96 & 5.2 & $\Theta$ & $4 y$ \\
\hline 5.8 & 1.99 & 78 & 7.2 & - & $4 \mathrm{y}$. \\
\hline 8.4 & 2.64 & 85 & 26.8 & - & $4 \mathrm{y} .5 \mathrm{~m}$ \\
\hline 10.1 & 2. 22 & 98 & 6.3 & - & $2 y .4 \mathrm{~m}$. \\
\hline 6.3 & 2.53 & 92 & 4.0 & - & 3 y. $5 \mathrm{~m}$. \\
\hline 35.9 & & 82 & 1.8 & - & $6 \mathrm{y}$ \\
\hline 7.8 & 1.92 & 109 & 16.0 & - & $4 \mathrm{y}$ \\
\hline 23.0 & & 83 & 19.8 & $\leftrightarrow$ & $0 \mathrm{y} .6 \mathrm{~m}$. \\
\hline 33.1 & 1.90 & 98 & 15.9 & - & $4 \mathrm{y}$. \\
\hline 33.0 & 2.10 & 133 & 11.5 & $\Leftrightarrow$ & $11 y$. \\
\hline 3.4 & 1.91 & 98 & 5.1 & - & $4 \mathrm{y}$ \\
\hline 47. 6 & 1.56 & 93 & 28.4 & $(-1)$ & 2 y. $2 \mathrm{~m}$. \\
\hline 2.4 & 1.90 & 108 & 2.1 & $(\oplus)$ & $3 \mathrm{y} .5 \mathrm{~m}$ \\
\hline 5.8 & 1.99 & 95 & 14.8 & - & $4 \mathrm{y}$ \\
\hline 4.9 & 2. 29 & 106 & 26.0 & 4 & $0 \mathrm{y} .8 \mathrm{~m}$. \\
\hline 37.6 & 1.75 & 101 & 8.1 & - & $4 \mathrm{y}$ \\
\hline 3.7 & 1.69 & 100 & 4.4 & - & $2 \mathrm{y} .3 \mathrm{~m}$. \\
\hline 41.7 & 1.84 & 90 & 5.5 & $\leftrightarrow$ & $4 \mathrm{y}$ \\
\hline 5.6 & 2. 37 & 86 & 0 & - & $2 \mathrm{y} .5 \mathrm{~m}$. \\
\hline 3.7 & 1.70 & 81 & 7.4 & - & 2 y. $4 \mathrm{~m}$. \\
\hline 7.0 & 2.74 & 122 & & - & $2 \mathrm{y}, 3 \mathrm{~m}$. \\
\hline 3.6 & 1.93 & 90 & 10.9 & - & $1 \mathrm{y} .1 \mathrm{~m}$. \\
\hline 5.5 & 2.00 & 82 & 17.9 & - & $4 \mathrm{y}$. \\
\hline 5.1 & & 114 & 7.0 & - & $3 \mathrm{y}$. \\
\hline 3.2 & 1.60 & 103 & 8.0 & - & $17 y$ \\
\hline $15.90 \pm 4.90$ & $2.04 \pm 0.12$ & $96.8 \pm 4.5$ & 10. $1 \pm 2.6$ & & \\
\hline
\end{tabular}

diphenylhydantoin administration (Group II), of which 5 cases (Nos. 42, 50, 59, 61 and 64) showed the positive ferric chloride reaction of the urine after the histidine load (the positive group), remaining 12 cases (Nos. 40, 43, 48, 55, 58, 60, $63,65,66,69,73$ and 74 ) having the negative ferric chloride reaction (the negative group). The results, shown in Table 3 , revealed that the average of serum histidine levels of the positive group was slightly higher than that of the negative group before and 4 hours after the histidine load, though the difference being not significant between the two groups in this experimental condition. 
From these clinical findings it was suspected that a decreased activity of the hepatic histidase might be brought about in some of patients with diphenylhydantoin therapy. This speculation was confirmed to be true by our results of animal experimentation, in which a marked decrease of the hepatic histidase activity was observed in rats given diphenylhydantoin in a dose of $500 \mathrm{mg}$ per $\mathrm{kg}$ per day for a period of 65 days (Arakawa et al. 1973).

(2) Urinary FlGLU after an oral histidine load (ef. Tables 1, 2 and 4 and Fig. 1): The average of FIGLU in $8 \mathrm{hr}$ urine after an oral histidine load was found to be $27.2 \pm 7.2 \mu$ moles and $10.1 \pm 2.1 \mu$ moles in Groups I and II, respectively,

TABLE 3. Serum histidine levels before and after an oral histidine load in patients with diphenylhydantoin administration

\begin{tabular}{c|c|c|c}
\hline \multirow{2}{*}{ No. of case } & $\begin{array}{c}\mathrm{FeCl}_{3} \text { test of urine } \\
\text { after histidine } \\
\text { loading }\end{array}$ & \multicolumn{2}{|c}{ Serum histidine $(\mathrm{mg} / 100 \mathrm{ml})$} \\
\hline 40 & - & Before & After histidine loading \\
43 & - & 1.09 & 6.00 \\
48 & - & 0.66 & 13.97 \\
55 & - & 1.29 & 14.69 \\
58 & - & 1.12 & 27.73 \\
60 & - & 1.23 & 13.61 \\
63 & - & 1.44 & 18.69 \\
65 & - & 1.23 & 12.29 \\
66 & - & 1.35 & 20.82 \\
69 & - & 1.16 & 9.98 \\
73 & - & 1.36 & 25.08 \\
74 & - & 1.24 & 24.34 \\
Average & - & $1.16 \pm 0.04$ & 28.61 \\
42 & + & 1.66 & $17.98 \pm 1.34$ \\
50 & + & 1.69 & 13.95 \\
59 & + & 1.33 & 20.82 \\
61 & + & 1.26 & 29.96 \\
64 & + & 1.26 & 16.01 \\
Average & & & 14.70 \\
& & & $19.08 \pm 9.34$
\end{tabular}

TABLE 4. Distribution of urinary FIGLU after an oral histidine load in mentally retarded patients with or without anticonvulsant therapy

\begin{tabular}{|c|c|c|c|c|}
\hline \multirow{2}{*}{$\begin{array}{c}\text { Urinary } \\
\text { FIGLU } \\
\text { (moles per } 8 \mathrm{hr} \text { ) }\end{array}$} & \multicolumn{2}{|c|}{$\begin{array}{l}\text { Group I } \\
\text { (without anticonvulsant therapy) }\end{array}$} & \multicolumn{2}{|c|}{$\begin{array}{l}\text { Group II } \\
\text { (with anticonvulsant therapy) }\end{array}$} \\
\hline & No. of cases & $(\%)$ & No. of cases & $(\%)$ \\
\hline $\begin{array}{l}l \\
30\end{array}$ & 19 & $(55.6)$ & 0 & $(0)$ \\
\hline $\begin{array}{c}29 \\
? \\
10\end{array}$ & 12 & $(33.3)$ & 13 & $(36.1)$ \\
\hline $\begin{array}{l}9 \\
? \\
0\end{array}$ & 4 & $(11.1)$ & 23 & $(63.9)$ \\
\hline Total & 35 & $(100)$ & 36 & $(100)$ \\
\hline
\end{tabular}




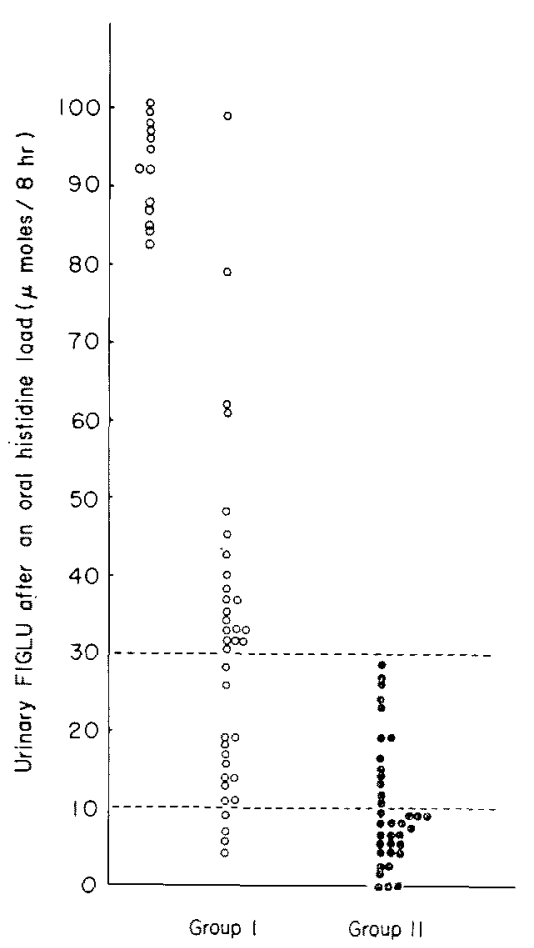

Fig. 1. Urinary FIGLU after an oral histidine load in Groups I and II.

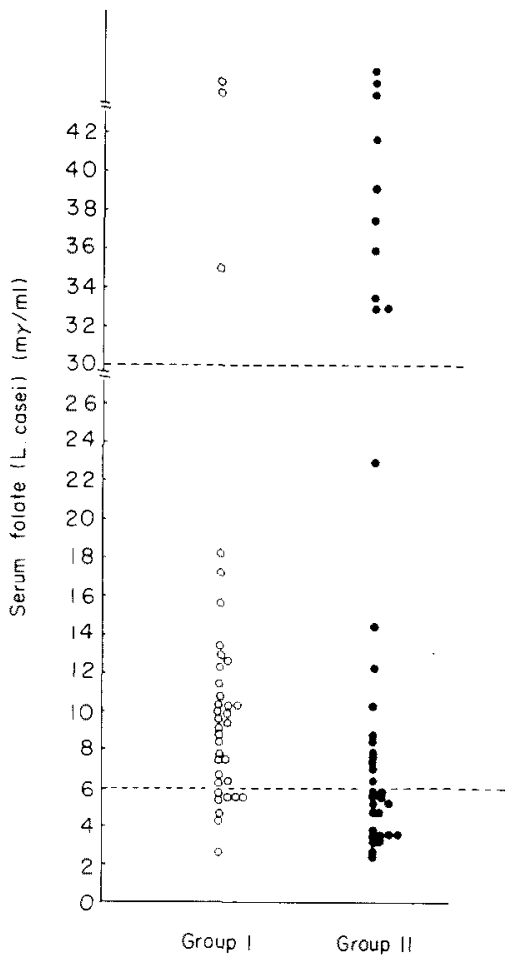

Fig. 2. Serum folate levels of Groups $\mathbf{I}$ and II.

the difference between two groups being statistically significant (cf. Tables $I$ and 2).

The finding that urinary FIGLU was significantly decreased in patients with diphenylhydantoin administration may be explained in the following way: In our preceding experiments it was found that a marked decrease in the hepatic histidase activity and a marked decrease in urinary FIGLU after a histidine load were brought about in rats by diphenylhydantoin administration. Less yielding of FIGLU from the histidine ingested due to a decreased hepatic histidase activity may contribute to a clecreased excretion of FIGLU after a histidine load in rats with diphenylhydantoin administration (Arakawa et al. 1973).

(3) Effect of diphenylhydantoin administration upon serum folate levels (cf. Tables 1 and 2): The averages of serum folate were found to be $12.9 \pm 4.3 \mathrm{~m} \gamma / \mathrm{ml}$ and $15.90 \pm 4.90 \mathrm{~m} \gamma / \mathrm{ml}$ in Groups I and II, respectively, showing no statistically significant difference in the average between two groups. However, Fig. 2 and Table 5 revealed that cases with serum folate above $30 \mathrm{~m} \gamma / \mathrm{ml}$ as well as those with serum folate below $5.9 \mathrm{~m} \gamma / \mathrm{ml}$ were increased in number in Group II as compared with those in Group I. The difference in the distribution of these cases was found to be statistically significant. This suggested that diphenylhydantoin administra- 
TABLE 5. Distribution of serum folate values of mentally retarded patients with or without anticonvulsant treatment

\begin{tabular}{|c|c|c|c|c|}
\hline \multirow{2}{*}{$\begin{array}{c}\text { Serum } \\
\text { folate } \\
(\mathrm{m} / / \mathrm{ml})\end{array}$} & \multicolumn{2}{|c|}{$\begin{array}{c}\text { Group I } \\
\text { (without anticonvulsant therapy) }\end{array}$} & \multicolumn{2}{|c|}{$\begin{array}{c}\text { Group II } \\
\text { (with anticonvulsant therapy) }\end{array}$} \\
\hline & No. of cases & $(\%)$ & No. of cases & $(\%)$ \\
\hline $\begin{array}{c}\text { ? } \\
30\end{array}$ & 3 & $(8.1)$ & 10 & $(27.0)$ \\
\hline $\begin{array}{l}29.9 \\
? \\
6.0\end{array}$ & 27 & $(70.1)$ & 10 & $(27.0)$ \\
\hline $\begin{array}{l}5.9 \\
? \\
0\end{array}$ & 7 & $(21.8)$ & 17 & $(46.07)$ \\
\hline Total & 37 & $(100)$ & 37 & (100) \\
\hline
\end{tabular}

tion caused either a rise or fall in serum folate levels of epileptic patients.

A decrease in serum folate levels of patients with anticonvulsant therapy has been well documented (Klipstein 1964; Reynolds et al. 1966; Dahlke and MertensRoesler 1967; Horwitz et al. 1968; Jensen and Olesen 1969; Houben et al. 1971). As for the mechanism through which subnormal serum folate levels developed in patients with the anticonvulsant therapy, several possibilities have been described, that is, an increased requirement of tetrahydrofolate for parahydroxylation of diphenylhydantoin (Kudd et al. 1964; Baylis et al. 1971), an interference with folic acid absorption due to inhibition of intestinal conjugase by diphenylhydantoin (Hoffbrand and Necheles 1968; Rosenberg et al. 1968) and so on.

However, there has been no report dealing with cases in which serum folate levels showed a tendency to rise during diphenylhydantoin administration.

(4) Serum vitamin $B_{12}$ levels in Groups $I$ and $I I$ (cf. Tables 1 and 2): The average of serum vitamin $B_{12}$ was found to be $0.43 \pm 0.05 \mathrm{~m} \gamma / \mathrm{ml}$ and $0.43 \pm 0.01$ $\mathrm{m} \gamma / \mathrm{ml}$ in Groups I and II, respectively, showing no difference between both groups.

No influence of anticonvulsant therapy upon serum vitamin $B_{12}$ levels of 56 epileptic patients, aged between 17 and 61 years, was reported by Jensen and Olesen in 1969.

Malpas et al. (1966) reported, however, a decreased serum vitamin $\mathrm{B}_{\mathbf{1 2}}$ level in epileptic pateints with anticonvulsant therapy.

(5) Mean corpuscular volume (MCV) of erythrocytes and the lobe average of neutrophils in Groups I and II (cf. Tables 1 and 2): The average of MCV was found to be $94.6 \pm 3.7 \mu^{3}$ and $96.8 \pm 4.5 \mu^{3}$ in Groups I and II, respectively, revealing no difference between two groups. Macrocytosis (MCV $>97 \mu^{3}$ ) was found in 16 cases out of 37 cases of Group I, and in 17 cases out of 37 cases of Group II, showing no difference in its incidence between two groups.

Eastham and Jancar (1970) reported that macrocytosis in the absence of anemia was demonstrated in the majority of mentally retarded epileptic patients 
who aged between 26 and 76 years and were receiving long-term anticonvulsant therapy. Furthermore, they stated that only patients over 25 years of age had been included into their study, because they found that mean red cell volume in non-anemic mentally retarded patients increased with patients' age from childhood onwards, the greatest rate of the increase occurring during a period between 10 years and 25 years of age (Eastham and Jancar, 1970). That the patients subjected to our study were ranging from 6 to 28 years in age might be a reason why a clear-cut effect of diphenylhydantoin administration was not observed in our study.

The lobe average of neutrophils showed also no difference between both groups, that is, being $2.14 \pm 0.18$ and $2.04 \pm 0.12$ in Groups $I$ and II, respectively.

Klipstein (1964) made hematologic investigation upon 60 adult patients with anticonvulsant therapy and found that macrocytosis was present in 23 out of 31 cases with subnormal serum folate levels and in 4 out of 22 cases with normal serum folate, and there was none with hypersegmentation of neutrophils in all the cases examined.

\section{References}

1) Arakawa, Ts., Honda, Y. \& Narisawa, K. (1973) Decreased hepatic histidase activity induced by diphenylhydantoin administration as a cause of decrease in urinary FIGLU in rats. Tohoku J. exp. Med., 110, $49-57$.

2) Baylis, E.M., Crowley, J.M., Preece, J.M., Sylvester, P.E. \& Marks, V. (1971) Influence of folic acid on blood phenytoin levels. Lancet, 1, 62-64.

3) Dahlke, M.B. \& Mertens-Roesler, E. ( 1967) Malabsorption of folic acid due to diphenylhydantoin. Blood, 30, 341--35l.

4) Eastham, R.D. \& Jancar, J. (1970) Mean red-cell volume and patient's age. Lancet, 1, 896-897.

5) Herbert, V. (1961) The assay and nature of folic acid activity in human serum. $J$. clin. Invest., 40, 81-91.

6) Herbert, V. (1965) Megaloblastic Anemias; Mechanisms and Management. Year Book Medical Publishers, Inc., Chicago.

7) Hoffbrand, A.V. \& Necheles, T.F. (1968) Mechanism of folate deficiency in patients receiving phenytoin. Lancet, 2, 528-530.

8) Horwitz, S.J., Klipstein, F.A. \& Lovelace, R.E. (1968) Relation of abnormal folate metabolism to neuropathy developing during anticonvulsant drug therapy. Lancet, 1, 563-565.

9) Houben, P.F.M., Hommes, O.R. \& Knaven, P.J.H. (1971) Anticonvulsant drugs and folic acid in young mentally retarded epileptic patients. Epilepsia, 12, 235247.

10) Humbel, R. (1970) Thin-layer chromatography of urinary imidazoles. Ctin. Chem., 16, $58-59$.

11) Jensen, O.N. \& Olesen, O.V. (1969) Folic acid and anticonvulsive drugs. Arch. Neurol., 21, 208-214.

12) Klipstein, F.A. (1964) Subnormal serum folate and macrocytosis associated with anticonvulsant drug therapy. Blood, 23, 68-86.

13) Kudd, H., Winters, W., Scherman, R. \& MeDowell, F. (1964) Diphenylhydantoin and phenobarbital toxicity. Arch. Neurol, 11, 649-656.

14) Lau, K.S., Gottlieb, C., Wasserman, L.R. \& Herbert, V. (1965) Measurement of serum vitamin $B_{12}$ level using radioisotope dilution and coated charcoal. Blood, 26, 202-214. 
15) Malpas, J.S., Spray, G.H. \& Witts, L.J. (1966) Serum folic acid and vitamin-B ${ }_{12}$ levels in anticonvulsant therapy. Brit. med., J., 1, 955-957.

16) Reynolds, E.H., Milner, G., Matthews, D.M. \& Chanarin, I. (1966) Anticonvulsant therapy, megaloblastic haemopoiesis and folic acid metabolism. Brain, 91, 197214.

17) Rosenberg, I.H., Godwin, H.A., Streiff, R.R. \& Castle, W.B. (1968) Impairment of intestinal deconjugation of dietary folate. Lancet, 2, 530-532.

18) Tabor, H. \& Wyngarden, L. (1959) The enzymatic formation of formiminotetrahydrofolic acid, 5, 10-methenyltetrahydrofolic acid, and 10-formyltetrahydrofolic acid in the metabolism of formiminoglutamic acid. J. biol. Chem., 234, 1830-1846. 